\title{
The Relation between Health Status and Internet Addiction among
}

\section{Adolescents}

\author{
Mona E. Shaheen, Demonstrator \\ Pediatric Nursing, Faculty of Nursing, Damanhour University \\ Yosur A. Gaafar, Professor \\ Pediatric Nursing, Faculty of Nursing, Alexandria University \\ Maha H. Mohammed Elshater, Lecturer \\ Pediatric Nursing, Faculty of Nursing, Alexandria University \\ Rodaina A. Mokbel, Lecturer \\ Pediatric Nursing, Faculty of Nursing, Damanhour University
}

\begin{abstract}
Internet plays a fundamental role in society. It is an easy access for information exchange and academic research. Prolonged use of internet can lead to internet addiction resulting in marked distress and/or functional impairment in psychological, physical and social daily life activities. Objective: Assess the relation between health status and internet addiction among adolescents. Setting: The study was conducted at outpatient clinics at Damanhour Medical National Institute. Subjects: Simple random sample of 200 adolescents of both sexes were included, their ages ranged from 13-18 years. Tools: Three tools were used; Socio-demographic Characteristics of the Adolescents and Their Pattern of Internet Usage, Internet Addiction Test and Assessment of Internet Addiction Consequences on the Health Status among Adolescents. Results: The present study revealed that the majority of the adolescents (87\%) used the internet daily and (85\%) of them used internet at night. The most commonly reported adverse physical effects were: eye irritation, followed by wrist \&arm pain, and numbness and tingling in the hand fingers. Nearly three-quarter of the adolescents (73.5\%) were eating junk food and skipping basic meals. Adolescents' sleep duration was affected by internet usage as reported by two thirds of adolescents (67\%). Two thirds of the adolescents' families complained about their prolonged duration of using internet. Half of adolescents (50\%) had bad mood during attempts to reduce the internet usage. Conclusion: Excessive internet use is associated with adverse health effects and unhealthy behaviors. Recommendations: A concentrated awareness program to be planned targeting school specialists and parents, and implementation of different workshops for adolescents about physical, psychological and social risks of excessive internet use.
\end{abstract}

Keywords: Internet Addiction; Health Status; Adolescents.

\section{Introduction}

Internet access and usage in the world has been proliferating year by year ${ }^{(1)}$. Internet plays a fundamental role in organizations and society. The term internet is defined as a large computer network that has many positive aspects and serves the life. It is an easy access to information exchange, academic research, entertainment, communication, commerce and business $^{(2,3,4)}$. So the number of internet users is increasing intensely to reach over 41 $\%$ of the world population ${ }^{(5)}$.

Frequent and prolonged periods of internet use are associated with physical, psychological and sociological problems in adolescents. Adolescence is a stressful life period, so there are many reasons that are responsible for making the adolescents as a probable risk group vulnerable to internet addiction. These reasons include: settle a lot of time on the internet for chatting, forming sites, socialization and searching about their peers' acceptance $^{(6)}$. In addition to, they 
develop a conflict with cultural and moral norms of society; those conflicts can cause a series of defense mechanisms that attracts adolescents to the internet as a form of relief $^{(6,7)}$.

Internet addiction is described with terminologies such as internet addiction disorder (IAD), Internet dependence, problematic Internet use, and compulsive Internet use $\mathrm{e}^{(8,9,10)}$.

Internet addiction (IA) always refers to the inability of individuals to control their Internet use, resulting in marked distress and/or functional impairment in psychological, physical and social daily life activities $^{(9,10,11)}$. In 2012, Diagnostic and Statistical Manual version fifth edition (DSM-V) stated the criteria of IA includes: preoccupation with internet use, tolerance, inability to control use, withdrawal symptoms, use the internet as a way to escape from problems, continued use of internet despite knowledge of negative consequences and loss of interests in previous hobbies ${ }^{(12,13,14)}$.

Internet addiction could negatively affect adolescent's health status. The negative consequences of IA on the physical health are mostly musculoskeletal disorders which are reported as back-ache, pain in the neck, wrist and shoulders ${ }^{(15)}$, as well as Computer vision syndrome, headache, migraine $^{(16,17)}$, poor diet quality and lower levels of physical activity. Sleep disturbance is another serious problem related to internet addiction $^{(18,19)}$.

Internet addiction has negative consequences not only on physical health, but also on social and psychological health. Internet has the power to affect the building and maintenance of social relations and reduces face-to-face communication ${ }^{(20,21,22)}$. In addition to, the psychological effects of IA which include increasing anger, irritability, nervousness and mood change when internet becomes offline ${ }^{(22) .}$

The pediatric nurse performs assessment to the adolescents through the clinical interview and an appropriate diagnosis can be given, then planning and implementation with the adolescent and their families can begin to learn the effective ways to change these behaviors ${ }^{(22)}$.

\section{Aim of the Study}

This study aimed to assess the relation between health status and internet addiction among adolescents.

\section{Research Question}

What is the relation between health status and internet addiction among adolescents?

\section{Materials and Method}

\section{Materials}

Design: A descriptive correlational design was used to accomplish this study.

Setting: The study was conducted at outpatient clinics (e.g., Dental clinic and Ear, Nose and throat clinic....etc.) at Damanhour Medical National Institute.

Subjects: Simple random sample of 200 adolescents attending the previously mentioned settings were selected randomly to constitute the subjects.

Tools: Three tools were used for data collection:

Tool I: Socio-Demographic Characteristics of the Adolescents and Their Pattern of Internet Usage Interview Questionnaire Sheet

This tool was developed by the researcher after reviewing the relevant literature and it included two parts:

Part I: Socio-demographic Data: It included data of adolescents such as: Age, gender, residence, estimated family monthly income, number of family members, parents' educational level and occupation.

Part II: Pattern of Internet Usage: It included: age at internet usage for the first time, frequency of using internet, average hours of internet usage daily, main purpose 
for usage, favorite place for internet usage, favorite time of internet use, ways of access to internet, .....etc.

\section{Tool II: Internet Addiction Test (IAT)}

The Internet Addiction Test (IAT) was developed originally by Dr. Kimberly Young (1996) to assess degree of internet addiction, It is a questionnaire composed of 20 -items that measures mild, moderate and severe levels of Internet Addiction and was originally scored on a 5-point Likert scale ranged from "rarely" to "always". Young, 2011 modified it to a 6-point scale with one response option being "does not apply". It includes 20 questions about some items such as: preoccupation with the internet, previous trials to control the internet usage, continued use of the internet despite the negative consequences, and the need to spend more time on the internet to gain satisfaction. Young, 2011 reported IAT as a reliable and valid measure of addictive use of Internet.

Scoring system: Responses to questions were measured on a six-point Likert scale that ranges from 0 to 5 as follows: $0=($ does not apply), 1 = (Rarely), $2=$ (Occasionally), $3=($ Frequently $), 4=($ Often $), 5=($ Always $)$.

The total score of the scale ranged from (0-100):

- 0-30 points: normal internet users.

- 31-49 points: indicates mild degree of internet addiction or an average on-line user.

- 50-79 points: means moderate degree of internet addiction or the user is experiencing occasional or frequent problems.

- 80-100 points: indicated severe degree of internet addiction or the Internet usage is causing significant problems in the user's life.

Tool III: Assessment of Internet Addiction Consequences on the Health Status among Adolescents Interview Questionnaire Sheet
It was developed by the researcher to assess internet addiction consequences on the health status among adolescents after reviewing the relevant literature and it included the following three parts.

Part I: Physical status: It included questions such as: physical discomfort symptoms, nutritional habits, sleeping pattern and type of physical exercise ...etc.

Part II: Social status: It included questions such as: how often they spend time with their parents and siblings per day, how many hours they spend with relatives, the number of actual friends they have and how much time they spend with them, number of friends on internet, and how much time they spend communicating with them, what do they prefer to do when feeling bored, having problems in face to face communication or building new friends or working in groups

Part III: Psychological status: It included questions such as: Feeling of sadness when being deprived from using the internet, feeling anxious, failure to adjust the number of hours in using internet and thinking in internet all the time....etc

\section{Method}

- An official letter from the Dean of the Faculty of Nursing, Alexandria University was sent to the responsible authorities of Damanhour Medical National Institute in order to gain permission to conduct the study after explaining its purpose.

- Ethical committee approval was taken on the proposal plan from the Faculty of Nursing, University of Alexandria.

- The research tool II "Internet Addiction Test" was translated into Arabic by the researcher and tested for its content validity by a jury of five experts in the field of the study and the necessary modifications were done accordingly.

- The research tool III "Assessment of internet addiction consequences on the 
health status among adolescents" was tested for its content validity by a jury of five experts in the field of the study and the necessary modifications were done accordingly.

- Tools II, III reliability was checked by Cronbach's alpha coefficient test.

- A pilot study was conducted on $10 \%$ of the study sample (20 adolescents) for testing feasibility and applicability of the tool and necessary modifications were done accordingly, then these $10 \%$ were excluded from the study sample.

- An explanation of the aim of the study was given before distribution of the interview questionnaire and the researcher gave any needed clarifications.

- The interview questionnaire was distributed among adolescents, and then recollected by the researcher.

- After completion of data collection, the necessary statistical analysis was done.

\section{Ethical considerations:}

- Permission was obtained to collect the data from the selected setting.

- A written informed consent was obtained from every student participated in the study after explaining the aim of the study and participants were assured that collected data was used only for the study purpose.

- Confidentiality of data, privacy and anonymity of all study subjects were maintained.

\section{Statistical Analysis}

- Data was analyzed using IBM SPSS (Statistical Package for Social Sciences) version 20 (Armonk, NY: IBM Corp, 2018) on a personal computer.
- Descriptive statistics: were done for qualitative data as number and percentage.

- Inferential analyses: for independent variables was done using CHI Square for relations.

- The level of significance was taken at $\mathrm{P}$ value $<0.05$ is statistically significant, otherwise is nonsignificant.

- The tests used for data analysis were:

a) Chi-square test: used for categorical variables to test the association between the variables.

b) Cronbach's Alpha: used for Reliability Statistics.

\section{Results}

Table (1) represents distribution of the adolescents according to their Sociodemographic characteristics. Two- thirds of adolescents $(67.5 \%)$ were females and onethird $(32.5 \%)$ were males. The highest percentage of adolescents (71.5\%), their ages ranged from 15 to less than 17 years. According to the academic year, half of the adolescents (52\%) were from the first secondary grade, while $19.5 \% \& 17 \%$ were from the second and third year orderly. nearly three- quarters of adolescents (74\%) were from urban areas.

Table (2) shows distribution of the adolescents regarding their pattern of internet usage. It reveals that forty five percent of adolescents used internet for 5 years and more. The most commonly used devices were the mobile phone and tablet as reported by nearly two-thirds of adolescents $(63.8 \%)$. More than two thirds of the adolescents $(70.4 \%)$ reported "home" as the most frequent place for internet access. The majority of the adolescents $(87 \%)$ used the internet daily. Concerning daily internet use, it was clear that $46.6 \%$ of adolescents used internet for 3 hours to less than 6 hours per 
day, while $11.5 \%$ of them used internet for 12 hours and more.

Table (3) reflects the distribution of the studied adolescents according to degree of internet addiction. It can be retrieved that half $(50.5 \%)$ of adolescents were classified as moderate internet addicts, while $(45 \%)$ of them were diagnosed as mild internet addicts and only minor percentage $(4.5 \%)$ were reported as severe internet addicts.

Table (4) shows the relationship between Daily Internet Usage in hours and Physical health complaints. It was apparent that $46.8 \%$ of adolescents who used internet $3-<6$ hours per day often complained from tired and red eyes, while $(51.7 \%, 55 \%, 51.4 \%$, $49.3 \%$ ) sometimes complained from (visualblurred vision, neck and shoulder pain, back pain, headache) respectively. It was also found that $(58 \%, 59.4 \%, 50.9 \%)$ of adolescents who sometimes complained from wrist and arm pain, numbness \& tingling in hand fingers and migraine used internet 3- $<6$ hours daily, these findings show statistically significant differences, where $(\mathrm{P}=0.000,0.006,0.007$ respectively).

Table (5) reflects the relationship between psychological health status and degree of internet addiction. More than half $(56.5 \%)$ of moderate internet addicts used internet as a way to escape the reality with statistically significant difference $\left(\mathrm{p}=0.003^{*}\right)$. In addition, two thirds of moderate internet addicts $(67.8 \%)$ were feeling comforted when using the internet continuously with statistically significant difference $(p=0.009)$. Nearly sixty of moderate internet addicts were often thinking about the internet with statistically significant difference $(\mathrm{p}=0.047)$. Two thirds of moderate internet addicts $(69.3 \%)$ were feeling violent and had aggressive behavior that was statistically significant $(p=0.000)$. Moreover, $60.9 \%$ of moderate internet addicts needed to increase number of hours for using the internet and there was a statistically significant difference $(\mathrm{p}=0.000)$. On the other hand, Sixty percent of moderate internet addicts tried to reduce their internet use but didn't succeed and it was statistically significant difference $(\mathrm{p}=0.032)$.

Table (6) simplifies the relationship between Daily Internet Usage in hours and Social Health. It was found that $(70.6 \%$, $57.1 \%$ ) of adolescents who used internet 3-6 hours daily, had (21-40, 81-100) online friends orderly with statistically significant difference $(\mathrm{p}=0.000)$. While $(60.5 \%$, $71.1 \%$ ) who used internet 3-6 hours and 12 hours or more daily, communicate with online friends 2-3 hours and 6 hours daily respectively, where $(\mathrm{p}=0.000)$.

\section{Discussion}

The Internet is a very important social and communication tool, but an explosive growth in the use of Internet leads to Internet addiction worldwide. Internet addiction (IA) is a major source for pathological compulsive Internet use among individuals especially adolescents ${ }^{(23,24)}$. It has many negative effects on physical, psychological and social health status ${ }^{(25)}$.

The current study revealed that twothirds of adolescents were females and onethird of them were males (table 1). These results are expected, because the female adolescent nature has a lot of leisure time at home and the male adolescent is occupied with extra activities (e.g. sporting, sitting with friends on café....etc) than internet use in their daily life. Ibrahim et al. (2016) findings were in agreement with the present findings as they explained that there is minor percent of male against female adolescents in internet usage experience ${ }^{(26)}$. Dissimilar to the earlier findings, $\mathrm{Wu}$ et al. (2017) reported that male adolescents' internet usage is more prevalent than female adolescents' internet usage ${ }^{(27)}$.

The present study clarified that the highest percentage of adolescents, their ages ranged from 15 to less than 17 years (table 1). It could be due to adolescents" less maturation mentally and psychologically. Furthermore, adolescents have many scholarly requirements and necessitates put 
them under massive stress. Therefore, they can't manage their online time appropriately. Karacic et al. (2017) results were consistent with the present results ${ }^{(28)}$. In contrast, the study conducted by Tsumura (2018) explained that internet addiction was strongly associated with both age 25-30 years old and high prevalence of IA and atrisk IA and the risk factors among employed adults in $\operatorname{Japan}^{(29)}$.

In addition, nearly three-quarters of adolescents were from urban areas, while only one fifth of them were from rural areas (table 1). It could be due to the character of urban life that tends to pass through difficult industrialized work and variety of machinery development. As well, the urban citizens have a prevalent employment of the internet profits and its technology than rural public. Sowndarya \& Pattar (2018) findings were congruent with the present study as they found that the occurrence of internet dependence amongst urban adolescents was higher than rural adolescents ${ }^{(30)}$.

As regard the number of years of internet usage among the adolescents, nearly half of adolescents tend to use the internet for the past five years (table 2). One explanation for this is that the adolescents used internet from childhood and puberty period not only from adolescence period. The findings of Saied et al. (2016) were consistent with the current study as they reported that the majority of adolescents used internet for five years and more $^{(24)}$.

Concerning with the device used for internet access, the current study presented that the most commonly used devices were the mobile phone and tablet as reported by two-thirds of adolescents (table 2). It could be due to the portability of the devices, their small size, their accessibility and recent development in features. Almasi et al. (2017) findings agreed with the present study as they described that more than half of secondary students accessed the internet from their mobile phones ${ }^{(31)}$. The study conducted by Lenhart et al. (2015) was incongruent with the present study as they showed that the majority of American teens accessed internet through a desktop or laptop computer, not through their phones $^{(32)}$.

Regarding to the location of internet use, it could be categorized into three places (home, internet café, and school). The present study stated that more than two thirds of the adolescents reported "home" as the most frequent place for internet access (table 2). It could be due to familiarity and low cost of home as a place. This implies that adolescents tend to access internet at free spot rather than paid location. Reda et al. (2012) findings were harmonious with the present study as they found that most of the adolescents have home internet access than other internet places ${ }^{(33)}$. As well, in Tanta University, Egypt, Saied et al. (2016) discussed that the majority of the Egyptian students have home internet access ${ }^{(24)}$. On contrary to the current findings, Almasi et al. (2017) discussed that there was a high percentage of students accessed the internet from the internet cafes; it could be due to loss of parental control and observation at internet café ${ }^{(31)}$.

About time spent on the internet, the existing findings showed that the majority of the adolescents used the internet daily, about half of them used internet for 3 hours to less than 6 hours per day (table 2). It could be attributed that this age group has a natural affinity and curiosity towards the internet and they have huge blocks of unstructured time. Consequently, this implies that internet has become a part of the daily lives of the users as they spent on internet nearly one quarter of the day. Norliah et al. (2017) and Rajasekhar et al. (2018) findings were in agreement with the present study as they reported that there were a high percentage of adolescents' internet users who spent more than quarter of the day using the internet ${ }^{(34,35)}$.

Concerning the degree of IA among the study participants, about half of the adolescents were classified as moderate internet addicts; while nearly half of them 
were diagnosed as mild internet addicts and only minor percentage were reported as severe internet addicts (table 3 ). This means that more than one half of them have many health problems, physically, socially and psychologically. This may be attributed firstly to the distinctive features of the internet that characterized by speed, accessibility, stimulation of its content, interactivity, simplicity, availability, and updated information that contributed to internet addiction. Nafee et al. (2018) results were similar to the current results ${ }^{(36)}$.

Moreover, the present study clarified that there were statistically significant differences between daily internet usage and physical health complaints (wrist and arm pain, numbness and tingling in hand fingers" repetitive stress injuries" and migraine). In addition, There wasn't significant difference between daily internet usage in hours and (tired and red eyes, visual-blurred vision) (table 4). It could be due to use the computers for extended periods of times and work in fixed sitting positions. In addition to lack of physical activities, this leads to malfunctioning and increasing the pain intensity. The findings of Saueressig (2015) and Derbyshire et al. (2013) were congruent with the present study as they found that significant relation between musculoskeletal complaints in both adolescents' genders and use of computers for more than 3 hours daily $^{(37,38)}$. Guzel (2018), Zheng et al. (2016) and Zein El Dein (2013) findings were congruent with the present study as they described that the higher quantity of time for the Internet use is intensely associated with a higher level of physical complaints (pain in arm \& wrist), also using a mouse and keyboard for many hours per day can lead to repetitive stress injuries ${ }^{(39,40,41)}$. Conversely, Custers et al. (2012) reported that the number of studies on the relationship between internet usage and physical health problems are rare. In contrast to the current study, Grabianowski (2012) stated that there was significant correlation between daily internet use and tired and red eyes (eye strain) ${ }^{(42,43)}$.
Pertaining to the relationship between psychological health status and degree of internet addiction, the present study explained that there was statistically significant difference between degree of internet addiction and escaping reality through using the internet and feeling comfortable (table 5). It could be due to the tendency of adolescents to escape their problems and stress from family and academic pressure by spending more time online. As well as, the adolescents who used the internet for chat, entertainment, and social networking activities are more likely to feel social acceptability, comfortable, and satisfaction. The present result is supported by Hammour et al. (2015) who found a strong association between internet addiction and escaping reality through using the internet, plus feeling comfortable during using internet ${ }^{(44)}$. In addition, Bonetti et al. (2010) confirmed that the Internet may be used as a way of "evading, procrastinating and escaping" from life's problems ${ }^{(45)}$.

The current study shows the positive correlation between thinking about the internet and degree of internet addiction (table 5). It could be due to characteristics and criteria of internet addiction that make adolescent preoccupied with internet and must be thinking about Internet and anticipating the next online session. Wanajak (2011) and Gmel, Notari \& Schneider (2017) results were consistent with the present study as they described that significant correlation was found between degree of internet addiction and preoccupation with Internet use ${ }^{(46,47)}$.

Furthermore, the existing study illustrated that degree of internet addiction was correlated significantly with aggressive behavior (table 5). These findings result from exposure of adolescents to computermediated social interaction, exposure to media violence, and entering a deindividuated state during Internet activities. Lim (2015) and Wanajak (2011) findings were congruent with the present study ${ }^{(46,48)}$. 
Regarding the relationship between daily internet usage per hours and social health, the current study confirmed that there was statistically significant difference between daily internet usage per hours and number of online friends and numbers of hours to communicate with them daily (table 6). It could be due to increased number of hours using internet leads to increased engagement of adolescents with internet activities, social websites, and communication with others. Khyal (2017) results were harmonious with the present study as they informed that there is statistical significant difference between increasing electronic media usage time and high number of friends on the internet and increasing time communicating with them $^{(49)}$.

\section{Conclusion}

Based on the findings of the current study, it can be concluded that the misuse of internet is very risky for adolescents. The most commonly reported adverse effects were: eye irritation, followed by wrist \&arm pain, and numbness and tingling in the hand fingers. The adolescents were eating junk food and skipping basic meals during using the internet. Adolescents' sleep duration was affected by internet usage. The adolescents' families sometimes complained about their duration of using internet. Adolescents had bad mood during attempts to reduce the internet usage. So, internet addiction is negatively associated with physical, psychological and social health status.

\section{Recommendations}

The main recommendations are:

- A concentrated awareness program to be planned targeting school specialists and parents regarding the adverse effect of internet use on adolescents and how to deal with it.

- Creating internet education unit in every school to teach adolescents about safe use of internet to prevent the addiction.

- Implementation of different workshops for adolescents about physical, psychological and social risks of excessive internet use.

- Increase facilities of sport and recreational activities through a special program to invite adolescents and occupy their leisure time.

- Collaboration between ministries of education, youth and sport, health and social affairs with the adolescents' families through an educational program and special websites for early detection of internet addiction. 
Table (1): Distribution of the studied adolescents according to their socio-demographic characteristics $(n=200)$

\begin{tabular}{||l|c|c||}
\hline Adolescents' characteristics & No & \% \\
\hline Sex & & \\
• Male & 65 & 32.5 \\
\hline Age & 135 & 67.5 \\
\hline$\quad 13-$ & & \\
- $15-$ & 23 & 11.5 \\
- $17-18$ years & 143 & 71.5 \\
\hline Academic year & 34 & 17.0 \\
- First preparatory grade & & \\
- Second preparatory grade & 2 & 1.0 \\
- Third preparatory grade & 10 & 5.0 \\
- First secondary grade & 11 & 5.5 \\
- Second secondary grade & 104 & 52.0 \\
- Third secondary grade & 39 & 19.5 \\
\hline Type of residence & 34 & 17.0 \\
- Urban & & \\
- Rural & 148 & 74.0 \\
\hline \hline
\end{tabular}

Table (2): Distribution of the studied adolescents regarding their internet usage pattern $(n=$ 200)

\begin{tabular}{|c|c|c|}
\hline Pattern of internet usage & No & $\%$ \\
\hline $\begin{array}{l}\text { Internet use in years } \\
\text { - One year } \\
\text { - Two years } \\
\text { - } \text { Three years } \\
\text { - Five years and more }\end{array}$ & $\begin{array}{l}31 \\
46 \\
33 \\
90\end{array}$ & $\begin{array}{l}15.5 \\
23.0 \\
16.5 \\
45.0\end{array}$ \\
\hline $\begin{array}{l}\text { Device(s) used for internet access }(\mathbf{n}=\mathbf{2 1 8}) \\
\text { 1. } \text { Personal computer } \\
\text { 2. } \text { Lab top } \\
\text { 3. } \text { Mobile/tablet } \\
1,2,3\end{array}$ & $\begin{array}{c}36 \\
12 \\
139 \\
31\end{array}$ & $\begin{array}{c}16.5 \\
5.5 \\
63.8 \\
14.2 \\
\end{array}$ \\
\hline $\begin{array}{ll}\text { Internet access place }(\mathbf{n}=\mathbf{2 1 3}) \\
\text { 1. } \\
\text { 2. Some } \\
\text { 3. } \text { Internet café } \\
\text { 4. } \text { Club } \\
1,2,3,4\end{array}$ & $\begin{array}{c}150 \\
8 \\
13 \\
4 \\
38\end{array}$ & $\begin{array}{c}70.4 \\
3.8 \\
6.1 \\
1.9 \\
17.8\end{array}$ \\
\hline $\begin{array}{l}\text { Frequency of internet use } \\
\text { - Daily } \\
\text { - Weekly }\end{array}$ & $\begin{array}{c}174 \\
26\end{array}$ & $\begin{array}{l}87.0 \\
13.0\end{array}$ \\
\hline $\begin{aligned} \text { Daily internet usage per hours } \\
\text { : } 1- \\
\text { : } 3- \\
\text { : } 6- \\
\text { : } 12 \text { hours and more }\end{aligned}$ & $\begin{array}{l}34 \\
81 \\
25 \\
14 \\
20\end{array}$ & $\begin{array}{c}19.5 \\
46.6 \\
14.4 \\
8.0 \\
11.5\end{array}$ \\
\hline
\end{tabular}


Table (3): Distribution of the studied adolescents according to degree of internet addiction $(\mathbf{n}=\mathbf{2 0 0})$

\begin{tabular}{|l|c|c|}
\hline \hline Degree of internet addiction & No & \% \\
\hline Mild degree of internet addiction & 90 & 45 \\
Moderate degree of internet addiction & 101 & 50.5 \\
Severe degree of internet addiction & 9 & 4.5 \\
\hline
\end{tabular}

Table (4): Relationship between daily internet usage in hours and physical health complaints $(n=174)$

\begin{tabular}{|c|c|c|c|c|c|c|c|c|c|c|c|}
\hline \multirow{3}{*}{$\begin{array}{l}\text { Physical health } \\
\text { complaints }\end{array}$} & \multicolumn{10}{|c|}{ Daily internet usage in hours } & \multirow{3}{*}{ Significance } \\
\hline & \multicolumn{2}{|c|}{$\begin{array}{c}1-<3 \text { hours } \\
\text { per day }\end{array}$} & \multicolumn{2}{|c|}{$\begin{array}{c}\text { 3- }<6 \text { hours } \\
\text { per day }\end{array}$} & \multicolumn{2}{|c|}{$\begin{array}{l}\text { 6- }<9 \text { hours } \\
\text { per day }\end{array}$} & \multicolumn{2}{|c|}{$\begin{array}{c}9-<12 \text { hours } \\
\text { per day }\end{array}$} & \multicolumn{2}{|c|}{$\begin{array}{l}12 \text { hours and } \\
\text { more per day }\end{array}$} & \\
\hline & No & $\%$ & No & $\%$ & No & $\%$ & No & $\%$ & No & $\%$ & \\
\hline \multicolumn{12}{|l|}{$\begin{array}{l}\text { Tired and red eyes (eye } \\
\text { strain) }\end{array}$} \\
\hline - Often & 23 & 16.5 & 65 & 46.8 & 22 & 15.8 & 12 & 8.6 & 17 & 12.2 & $\chi 2=9.693$ \\
\hline - Sometimes & 7 & 38.9 & 7 & 38.9 & 0 & 0.0 & 2 & 11.1 & 2 & 11.1 & \\
\hline - $\quad$ Never & 4 & 23.5 & 9 & 52.9 & 3 & 17.6 & 0 & 0.0 & 1 & 5.9 & \\
\hline \multicolumn{12}{|l|}{ Visual-blurred vision } \\
\hline - Often & 9 & 25.7 & 12 & 34.3 & 2 & 5.7 & 4 & 11.4 & 8 & 22.9 & $\chi 2=10.777$ \\
\hline - Sometimes & 11 & 19.0 & 30 & 51.7 & 8 & 13.8 & 4 & 6.9 & 5 & 8.6 & $\mathrm{p}=0.215$ \\
\hline - $\quad$ Never & 14 & 17.3 & 39 & 48.1 & 15 & 18.5 & 6 & 7.4 & 7 & 8.6 & \\
\hline \multicolumn{12}{|l|}{ Neck and shoulder pain } \\
\hline - Often & 25 & 20.0 & 55 & 44.0 & 19 & 15.2 & 11 & 8.8 & 15 & 12.0 & $\chi 2=4.084$ \\
\hline - Sometimes & 6 & 15.0 & 22 & 55.0 & 5 & 12.5 & 2 & 5.0 & 5 & 12.5 & $\mathrm{p}=0.849$ \\
\hline - $\quad$ Never & 3 & 33.3 & 4 & 44.4 & 1 & 11.1 & 1 & 11.1 & 0 & 0.0 & \\
\hline \multicolumn{12}{|l|}{ Back pain } \\
\hline - Often & 25 & 18.5 & 61 & 45.2 & 20 & 14.8 & 13 & 9.6 & 16 & 11.9 & $\chi 2=6.308$ \\
\hline - Sometimes & 8 & 22.9 & 18 & 51.4 & 5 & 14.3 & 0 & 0.0 & 4 & 11.4 & $\mathrm{p}=0.613$ \\
\hline - $\quad$ Never & 1 & 25.0 & 2 & 50.0 & 0 & 0.0 & 1 & 25.0 & 0 & 0.0 & \\
\hline \multicolumn{12}{|l|}{ Wrist and arm pain } \\
\hline - Often & 7 & 23.3 & 7 & 23.3 & 3 & 10.0 & 5 & 16.7 & 8 & 26.7 & $\chi 2=21.339$ \\
\hline - Sometimes & 14 & 20.3 & 40 & 58.0 & 9 & 13.0 & 1 & 1.4 & 5 & 7.2 & $\mathrm{p}=0.006^{* *}$ \\
\hline - $\quad$ Never & 13 & 17.3 & 34 & 45.3 & 13 & 17.3 & 8 & 10.7 & 7 & 9.3 & \\
\hline \multicolumn{12}{|l|}{ Numbness and tingling in } \\
\hline - Often & 11 & 31.4 & 7 & 20.0 & 5 & 14.3 & 2 & 5.7 & 10 & 28.6 & $\chi^{2}=31.334$ \\
\hline - Sometimes & 8 & 12.5 & 38 & 59.4 & 4 & 6.3 & 8 & 12.5 & 6 & 9.4 & \\
\hline - $\quad$ Never & 15 & 20.0 & 36 & 48.0 & 16 & 21.3 & 4 & 5.3 & 4 & 5.3 & \\
\hline \multicolumn{12}{|l|}{ Headache } \\
\hline - Often & 14 & 23.7 & 24 & 40.7 & 7 & 11.9 & 5 & 8.5 & 9 & 15.3 & $\chi 2=12.636$ \\
\hline - Sometimes & 16 & 23.9 & 33 & 49.3 & 7 & 10.4 & 7 & 10.4 & 4 & 6.0 & $\mathrm{p}=0.125$ \\
\hline - $\quad$ Never & 4 & 8.3 & 24 & 50.0 & 11 & 22.9 & 2 & 4.2 & 7 & 14.6 & \\
\hline \multicolumn{12}{|l|}{ Migraine } \\
\hline - Often & 7 & 20.0 & 12 & 34.3 & 3 & 8.6 & 3 & 8.6 & 10 & 28.6 & $\chi 2=21.035$ \\
\hline - Sometimes & 6 & 10.9 & 28 & 50.9 & 12 & 21.8 & 3 & 5.5 & 6 & 10.9 & $\mathrm{p}=0.007 * *$ \\
\hline - $\quad$ Never & 21 & 25.0 & 41 & 48.8 & 10 & 11.9 & 8 & 9.5 & 4 & 4.8 & \\
\hline
\end{tabular}

** Statistically significant at $p<0.001$ 
Table (5): Relationship between psychological health status and degree of internet addiction (n=200)

\begin{tabular}{|c|c|c|c|c|c|c|c|}
\hline \multirow[t]{2}{*}{ Psychological health status } & \multicolumn{2}{|c|}{$\begin{array}{c}\text { Mild } \\
\text { internet } \\
\text { addicts }\end{array}$} & \multicolumn{2}{|c|}{$\begin{array}{l}\text { Moderate } \\
\text { internet } \\
\text { addicts }\end{array}$} & \multicolumn{2}{|c|}{$\begin{array}{l}\text { Sever } \\
\text { internet } \\
\text { addicts }\end{array}$} & Significance \\
\hline & No & $\%$ & No & $\%$ & No & $\%$ & \\
\hline $\begin{array}{l}\text { Escaping reality through using the } \\
\text { internet } \\
\text { - Often } \\
\text { - Sometimes } \\
\text { - Never }\end{array}$ & $\begin{array}{l}16 \\
36 \\
38\end{array}$ & $\begin{array}{l}34.8 \\
36.7 \\
67.9\end{array}$ & $\begin{array}{l}26 \\
58 \\
17\end{array}$ & $\begin{array}{l}56.5 \\
59.2 \\
30.4\end{array}$ & $\begin{array}{l}4 \\
4 \\
1\end{array}$ & $\begin{array}{l}8.7 \\
4.1 \\
1.8\end{array}$ & $\begin{array}{c}\chi 2=19.779 \\
P=0.003^{*}\end{array}$ \\
\hline $\begin{array}{l}\text { Comfort sensation when using the } \\
\text { Internet continuously. } \\
\text { - Often } \\
\text { - Sometimes } \\
\text { - Never }\end{array}$ & $\begin{array}{l}16 \\
47 \\
27\end{array}$ & $\begin{array}{l}27.1 \\
49.5 \\
58.7\end{array}$ & $\begin{array}{l}40 \\
42 \\
19\end{array}$ & $\begin{array}{l}67.8 \\
44.2 \\
41.3\end{array}$ & $\begin{array}{l}3 \\
6 \\
0\end{array}$ & $\begin{array}{l}5.1 \\
6.3 \\
0.0\end{array}$ & $\begin{array}{l}\chi 2=17.196 \\
p=0.009 * *\end{array}$ \\
\hline $\begin{array}{l}\text { thinking about the Internet } \\
\text { - Often } \\
\text { - Sometimes } \\
\text { - Never }\end{array}$ & $\begin{array}{l}15 \\
36 \\
39\end{array}$ & $\begin{array}{l}28.8 \\
46.2 \\
55.7\end{array}$ & $\begin{array}{l}32 \\
40 \\
29\end{array}$ & $\begin{array}{l}61.5 \\
51.3 \\
41.4\end{array}$ & $\begin{array}{l}5 \\
2 \\
2\end{array}$ & $\begin{array}{l}9.6 \\
2.6 \\
2.9\end{array}$ & $\begin{array}{l}\chi 2=12.773 \\
\mathrm{p}=0.047^{*}\end{array}$ \\
\hline $\begin{array}{l}\text { had aggressive behavior } \\
\text { - } \quad \text { Yes } \\
\text { - } \quad \text { No }\end{array}$ & $\begin{array}{l}18 \\
71\end{array}$ & $\begin{array}{l}24.0 \\
57.6\end{array}$ & $\begin{array}{l}52 \\
49\end{array}$ & $\begin{array}{l}69.3 \\
39.2\end{array}$ & $\begin{array}{l}5 \\
4\end{array}$ & $\begin{array}{l}6.7 \\
3.2 \\
\end{array}$ & $\begin{array}{l}\chi 2=21.613 \\
p=0.000^{* *}\end{array}$ \\
\hline $\begin{array}{l}\text { increasing time of using the Internet } \\
\text { - Yes } \\
\text { - } \quad \text { No }\end{array}$ & $\begin{array}{l}35 \\
55\end{array}$ & $\begin{array}{l}31.8 \\
61.1\end{array}$ & $\begin{array}{l}67 \\
34\end{array}$ & $\begin{array}{l}60.9 \\
37.8\end{array}$ & $\begin{array}{l}8 \\
1\end{array}$ & $\begin{array}{l}7.3 \\
1.1\end{array}$ & $\begin{array}{l}\chi 2=19.478 \\
p=0.000^{* *}\end{array}$ \\
\hline $\begin{array}{l}\text { trials to reduce the time spent online } \\
\text { - I did not try } \\
\text { - Yes I tried and did not succeed } \\
\text { - Yes I tried and succeeded }\end{array}$ & $\begin{array}{l}25 \\
28 \\
37\end{array}$ & $\begin{array}{l}48.1 \\
32.9 \\
58.7\end{array}$ & $\begin{array}{l}25 \\
51 \\
25\end{array}$ & $\begin{array}{l}48.1 \\
60.0 \\
39.7\end{array}$ & $\begin{array}{l}2 \\
6 \\
1\end{array}$ & $\begin{array}{l}3.8 \\
7.1 \\
1.6\end{array}$ & $\begin{array}{c}\chi^{2}=13.810 \\
\mathrm{p}=0.032 *\end{array}$ \\
\hline
\end{tabular}


Table (6): Relationship between daily internet usage in hours and social health $(n=174)$

\begin{tabular}{|c|c|c|c|c|c|c|c|c|c|c|c|}
\hline \multirow{3}{*}{ Social health } & \multicolumn{10}{|c|}{ Daily internet usage in hours } & \multirow{3}{*}{ Significance } \\
\hline & \multicolumn{2}{|c|}{$\begin{array}{c}1-<3 \text { hours } \\
\text { per day }\end{array}$} & \multicolumn{2}{|c|}{$\begin{array}{c}\text { 3- }<6 \text { hours } \\
\text { per day }\end{array}$} & \multicolumn{2}{|c|}{$\begin{array}{c}\text { 6- }<9 \text { hours } \\
\text { per day }\end{array}$} & \multicolumn{2}{|c|}{$\begin{array}{c}\text { 9- }<12 \text { hours } \\
\text { per day }\end{array}$} & \multicolumn{2}{|c|}{$\begin{array}{l}12 \text { hours and } \\
\text { more per day }\end{array}$} & \\
\hline & No & $\%$ & No & $\%$ & No & $\%$ & No & $\%$ & & $\%$ & \\
\hline \multicolumn{12}{|l|}{ Sit with your family daily } \\
\hline - $\quad$ Yes & 30 & 21.4 & 64 & 45.7 & 23 & 16.4 & 11 & 7.9 & 12 & 8.6 & $\begin{array}{l}\chi 2=8.890 \\
p=0.064\end{array}$ \\
\hline - $\quad$ No & 4 & 11.8 & 17 & 50.0 & 2 & 5.9 & 3 & 8.8 & 8 & 23.5 & \\
\hline \multicolumn{12}{|l|}{$\begin{array}{l}\text { Number of hours sit with } \\
\text { family }\end{array}$} \\
\hline - one hour & 8 & 42.1 & 8 & 42.1 & 2 & 10.5 & 1 & 5.3 & 0 & 0.0 & $\chi 2=18.602$ \\
\hline - Two hours & 5 & 13.9 & 18 & 50.0 & 6 & 16.7 & 4 & 11.1 & 3 & 8.3 & \\
\hline - Three hours & 3 & 11.5 & 13 & 50.0 & 8 & 30.8 & 2 & 7.7 & 0 & 0.0 & $\mathrm{p}=0.099$ \\
\hline - $\quad$ Four hours & 14 & 23.7 & 25 & 42.4 & 7 & 11.9 & 4 & 6.8 & 9 & 15.3 & \\
\hline \multicolumn{12}{|l|}{ Number of close friends } \\
\hline - No close friends & 1 & 25.0 & 2 & 50.0 & 0 & 0.0 & 0 & 0.0 & 1 & 25.0 & \\
\hline - About 1-2 friends & 14 & 28.0 & 17 & 34.0 & 6 & 12.0 & 6 & 12.0 & 7 & 14.0 & $\chi 2=19.431$ \\
\hline - Between 3-5 friends & 9 & 13.8 & 36 & 55.4 & 12 & 18.5 & 4 & 6.2 & 4 & 6.2 & \\
\hline $\begin{array}{l}\text { With a rate of 6-10 } \\
\text { friends }\end{array}$ & 3 & 15.8 & 10 & 52.6 & 4 & 21.1 & 2 & 10.5 & 0 & 0.0 & $\mathrm{p}=0.24 /$ \\
\hline $\begin{array}{l}\text { More than } 10 \\
\text { friends }\end{array}$ & 7 & 19.4 & 16 & 44.4 & 3 & 8.3 & 2 & 5.6 & 8 & 22.2 & \\
\hline \multicolumn{12}{|l|}{ Number of online friends } \\
\hline - 5-20 friends & 16 & 48.5 & 11 & 33.3 & 0 & 0.0 & 4 & 12.1 & 2 & 6.1 & $\chi 2=48.150$ \\
\hline - $\quad 21-40$ friends & 3 & 8.8 & 24 & 70.6 & 3 & 8.8 & 0 & 0.0 & 4 & 11.8 & $\mathrm{p}=0.000 * *$ \\
\hline - $\quad 41-60$ friends & 3 & 25.0 & 6 & 50.0 & 2 & 16.7 & 0 & 0.0 & 1 & 8.3 & \\
\hline - $\quad 61-80$ friends & 3 & 25.0 & 6 & 50.0 & 2 & 16.7 & 0 & 0.0 & 1 & 8.3 & \\
\hline - $\quad 81-100$ friends & 2 & 28.6 & 4 & 57.1 & 1 & 14.3 & 0 & 0.0 & 0 & 0.0 & \\
\hline $\begin{array}{l}\text { - More than } 100 \\
\text { friends }\end{array}$ & 7 & 9.3 & 29 & 38.7 & 17 & 22.7 & 10 & 13.3 & 12 & 16.0 & \\
\hline \multicolumn{12}{|l|}{$\begin{array}{l}\text { Number of hours } \\
\text { communicate with online } \\
\text { friends daily }\end{array}$} \\
\hline - 1 hour & 21 & 32.8 & 27 & 42.2 & 8 & 12.5 & 5 & 7.8 & 3 & 4.7 & \\
\hline - $\quad 2-3$ hours & 10 & 12.3 & 49 & 60.5 & 11 & 13.6 & 5 & 6.2 & 6 & 7.4 & $\begin{array}{c}\chi 271.243 \\
\mathrm{p}=0.000 * *\end{array}$ \\
\hline - 3-4 hours & 0 & 0.0 & 3 & 42.9 & 4 & 57.1 & 0 & 0.0 & 0 & 0.0 & \\
\hline - 4-5 hours & 2 & 13.3 & 2 & 13.3 & 2 & 13.3 & 3 & 20.0 & 6 & 40.0 & \\
\hline - 6 hours and more & 1 & 14.3 & 0 & 0.0 & 0 & 0.0 & 1 & 14.3 & 5 & 71.4 & \\
\hline $\begin{array}{l}\text { Participating in social } \\
\text { activities (events and social } \\
\text { visits) }\end{array}$ & & & & & & & & & & & \\
\hline - Often & 11 & 22.4 & 20 & 40.8 & 6 & 12.2 & 5 & 10.2 & 7 & 14.3 & $\begin{array}{l}\chi 2=4.082 \\
\mathrm{p}=0.850\end{array}$ \\
\hline - Sometimes & 16 & 17.4 & 44 & 47.8 & 13 & 14.1 & 8 & 8.7 & 11 & 12.0 & \\
\hline - $\quad$ Never & 7 & 21.2 & 17 & 51.5 & 6 & 18.2 & 1 & 3.0 & 2 & 6.1 & \\
\hline
\end{tabular}

**Statistically significant at $p<0.001$ 


\section{References}

1. Gencer, S., Koc, M. (2012). Internet Abuse among Teenagers and Its Relations to Internet Usage Patterns and Demographics. Demographics Educational Technology \& Society, 15(2), 25-7.

2. George, L. (2016). The Relation between Physical Activity and the use of Internet in Schoolchildren. The Swedish Journal of Scientific Research, 3(11), 1-3.

3. Ogungbeni, J., Adekanye, A., Bamigbose, A., Sulaiman, M. (2016). Internet Use among Undergraduates in Nigeria: The Role of Policy. Information and Knowledge Management, 6(6), 89-90.

4. Peter, M. (2012). Internet Usage and Students' Academic Performance in Nigeria Tertiary Institutions: A Case Study of University of Maiduguri. Academic Research International, 2(3), 334-6.

5. Internet world stats. Internet users in December 31, 2017. Miniwittas Marketing Group; 2018. Available at: http://www.internetworldstats.com/stats.htm

6. Kumar, R., Basnet, S., Raj, K., Sah, P., Adhikari, K. (2016). Facebook use and its effects on the life of health science students in a private medical college of Nepal. BMC Research Notes, 9, 375-8.

7. Evren, C., Dalbudak, E., Evren, B., Demirci, A. (2014). High Risk of Internet Addiction and Its Relationship with Lifetime Substance Use, Psychological and Behavioral Problems among 10th Grade Adolescents. Psychiatria Danubina, 26(4), 330-9.

8. Gholamian, B., Shahnazi, H., Hassanzadeh, A. (2017). The Prevalence of Internet Addiction and its Association with Depression, Anxiety, and Stress, among High-School Students. Int J Pediatr, 5(4), 4763-70. 2

9. Lawrence, T. (2014). Risk Factors of Internet Addiction and the Health Effect of Internet Addiction on Adolescents: A Systematic Review of Longitudinal and Prospective Studies. Curr Psychiatry Rep, 16, 508-10.

10. Antonius, J., Christopher, J., Tim, M. (2017). Time to Abandon Internet Addiction? Predicting Problemtic Internet, Game, and Social media Use from Psychosocial Well-being and Application Use. Clinical Neuropsychiatry, 14(1), 113-21.

11. Krishnamurthy, S., Chetlapalli, S. (2015). Internet addiction: Prevalence and risk factors: A cross-sectional study among college students in Bengaluru, the Silicon Valley of India. Indian J Public Health, 59, 115-21.

12. Fineberg, N., Demetrovics, Z., Stein, D., Ioannidis, K., Potenza, M., Grünblatt, E. (2018). Manifesto for a European research network into Problematic Usage of the Internet. European Neuropsychopharmacol, 28(11), 1232-46.
13. Saliceti, F. (2015). Internet Addiction Disorder (IAD). Procedia - Social and Behavioral Sciences, 191, 1372-1376.

14. Tao, R., Huang, X., Wang, J., Zhang, H., Zhang, Y., Li, M. (2010). Proposed diagnostic criteria for internet addiction. Society for The study of Addiction, 105(3), 381-390.

15. Rodrigues, G., Carolina, A., Katherine, M., Aurélio, M. (2016). Prevalence of musculoskeletal pain in adolescents and association with computer and videogame use. Jornal de Pediatria, 92(2), 1-5.

16. Mohan, M. (2012). Computer vision syndrome. Health, 90(8), 30-35.

17. World Health Organization. (2015). Public health implications of excessive use of the internet, computers, smartphones and similar electronic devices: meeting report, Main Meeting Hall, Foundation for Promotion of Cancer Research, National Cancer Research Centre, Tokyo, Japan, 27-29 August 2014. Available https://apps.who.int/iris/handle/10665/184264

18. The Sleep Council (United Kingdom): The Good-night Guide for Children 2012. (Assessed at http://www.sleepcouncil.org.uk/pdfdownloads/the good_night_guide_for_children. pdf. (March 2014).

19. Sleep Health Foundation, Australia. 2014. Available at: http://www.sleephealthfoundation.org.au factsheets-a-z/224-sleep-tips-for-children.html.

20. Khalid, A. (2017). Impact of Internet on Social Connections in Family System: A Survey Study of Residents in Lahore. Arts and Social Sciences Journal, 8(3), 1-6.

21. Chan, C. (2014). Health Effects of Use of Internet and Electronic Screen Products. Department of health. The government of Hong Kong special administrative region. Available at:

https://www.studenthealth.gov.hk/english/intern et/press/press.html.

22. Nabuco, C., Young, k. (2011). Internet addiction: A Handbook and guide to evaluation and Treatment. 1st ed. Canada: John Wiley \& Sons, Inc, 3-40.

23. Mohamed, A., El- Sayed, S. (2017). Incentives for Using Internet and Its Addiction among Adolescents in Rural Area in Tanta City, Egypt.IOSR Journal of Nursing and Health Science, 6(3), 79-91.

24. Saied, S., Elsabagh, H., \& El-Afandy, A. (2016). Internet and Facebook addiction among Egyptian and Malaysian medical students: a comparative study, Tanta University, Egypt. International Journal of Community Medicine and Public Health, 3(5), 1288-97.

25. Halley, M., Daria, J., Mark, D. (2015). Clinical psychology of Internet addiction: a review of its conceptualization, prevalence, neuronal 
processes, and implications for treatment. Neuroscience and Neuroeconomics, 3(4), 11-5.

26. Ibrahim, A., Akel, D.,Abd El Fatah, L., Mohammad Othman Abudari, M. (2016). Emotional intelligence and internet addiction among nursing interns. Clinical Nursing Studies, 4(1), 1-15.

27. Wu, C., Wong, H., Yu, K., Fok, K., Yeung, S., Lam, C., Liu, K. (2016). Parenting approaches, family functionality, and internet addiction among Hong Kong adolescents. BMC Pediatrics, 16, 1-10

28. Karacic, S., \& Oreskovic, S. (2017). Internet Addiction and Mental Health Status of Adolescents in Croatia and Germany. Psychiatria Danubina, 29(3), 313-21.

29. Tsumura, H., Kanda, H., Sugaya, N., Tsuboi, S., Takahashi, K. (2018). Prevalence and Risk Factors of Internet Addiction among Employed Adults in Japan. Journal of Epidemiology, 28(4), 202-6

30. Sowndarya, T., \& Pattar, M. (2018). Pattern of internet addiction among urban and rural school students, Mangaluru, India: a comparative cross-sectional study. International Journal of Contemporary Pediatrics, 5(5), 1-5.

31. Almasi, M., Machumu, H., Zhu, C. (2017). Internet use among secondary school students and its effects on their learning. The 11th annual International Technology, Education and Development Conference, 2382-7. Available at: https://www.researchgate.net/publication/31384 3142

32. Lenhart, A. (2015). Teen, Social Media and Technology Overview 2015. Pew Research Center, 1-48. Available at: http://www.pewinternet.org/2015/04/09/teenssocial-media-technology-2015.

33. Reda, M., Rabie, M., Mohsen, N., Hassan, A. (2012). Problematic internet users and psychiatric morbidity in a sample of Egyptian adolescents. Psychology, 3(8), 626-31.

34. Norliah, K., et al. (2017). Internet usage pattern and types of internet users among Malaysian university students.Journal of engineering and applied sciences, 12(6), 1433-9.

35. Rajasekhar, P., Veena, C., \& Kumar, S. (2018). Gender differences in internet preferences and usage pattern among medical students. National Journal of Physiology, Pharmacy and Pharmacology, 8(5), 683-6.

36. Nafee, H., Mohammed, B., Ahlam, Y., AlHamdan, A. (2018). Effect of excessive internet use in Saudi and Egyptian teenagers' health: Comparative study. Journal of Nursing Education and Practice, 8(9), 25-35.

37. Saueressig, I., Oliveira, V., \& Xavier, M. (2015). Prevalence of musculoskeletal pain in adolescents and its association with the use of electronic devices. Rev Dor, 16(2), 129-35.

38. Derbyshire, K., Lust, K., Schreiber, L., et al. (2013). Problematic Internet use and associated risks in a college sample. Comprehensive Psychiatry, 54(5), 415-22.

39. Guzel, N., Kahveci, I., Solak, N., Comert, M., Turan, F N. (2018). Internet Addiction and Its Impact on Physical Health. Turkish Med. Stud. J, 5, 32-36. DOI: 10.4274/tmsj.2018.05.03.0002

40. Zheng, Y., Wei, D., Li, J., Zhu, T., Ning, H. (2016). Internet Use and Its Impact on Individual Physical Health. IEEE acess, 4(5), 5135-42.

41. Zein El Dein, N. (2013). Harmful Effect of Commonly Used Electronic Devices on Adolescence and its Safeguard at Shebin ElKom. Journal of Nursing and Health Science, 2(1), 32-46.

42. Custers, K., Bulck, J. (2012). Television viewing, internet use, and self-reported bedtime and rise time in adults: implications for sleep hygiene recommendations from an exploratory cross-sectional study. Behavioral Sleep Medicine, 10, 96-105.

43. Grabianowski, E. (2012). How Computer addiction Works Kansas State University. 19982012 How Stuff Works, Inc (11), Information Center, Egyptian Journal of El Ahram.

44. Hammour, Z., Abd-Elgalil, H., Elhassan, H., Abo Alabbas, M. (2015). Problematic Internet Use among Al-Azhar University Students in Cairo. The Egyptian Journal of Hospital Medicine, 61, 535-47.

45. Bonetti, L., Campbell, M., Gilmore, L. (2010). The relationship of loneliness and socialanxiety with children's and adolescents' online communication. Cyberpsychology, Behavior, and Social Networking, 13, 279-85

46. Wanajak, K. (2011). Internet Use and Its Impact on Secondary School Students In Chiang Mai, Thailand. Doctorate Thesis. Faculty of Computing, Health and Science. Edith Cowan University.

47. Gmel, G., Notari, L., \& Schneider, E. (2017). Is there an Internet Addiction and what distinguishes it from problematic Internet use An attempt to provide working definitions? Sucht Schweiz Lausanne, Addiction Switzerland, 5-67.

48. Lim, J., Gwak, A., Park, S. M., Kwon, J., Lee, J., Jung, H., \& Sohn, B. K. (2015). Are Adolescents with Internet Addiction Prone to Aggressive Behavior? The Mediating Effect of Clinical Comorbidities on the Predictability of Aggression in Adolescents with Internet Addiction. Cyberpsychol Behav Soc Netw, 18(5), 260-267

49. Khyal, D. (2017). Impact of Electronic Media on Child Physical, Cognitive, Social and Behavioral Development. Master thesis. Department of pediatrics, Faculty of Medicine, Benha University. 